\title{
Prediction of Consumer Purchase Decision using Demographic Variables: A Study with Reference to Premium Car
}

\author{
Dr. S. Prem Kumar, \\ Associate Professor, Department of Sports Management, Tamil Nadu Physical Education and Sports University, \\ Chennai - 600 127, India.
}

\begin{abstract}
The demographic environment is of major interest to marketers because it involves people and people make up market. Fragmentation of the mass market into numerous micro markets differentiated by age, sex, education, life style, geography and so on. Because each group has strong preferences and consumer characteristics that can be easily reached through increasingly targeted communication and distribution channels. Most of marketers' strategic decision making heavily depend on the demographic variables of people in the region where they focus on marketing their products. This study makes known the vital demographic structure of premium car owners in Chennai city and provides models for predicting the consumer's decision to buy a car when his exact demographic profile is known. The relationship established between the demographic variables and the different stages of consumer's purchase decision process further helps identifying the significant demographic variables. This will be definitely helpful to the marketers of cars to know their target group and to evolve marketing strategies to make them becoming a car owner.
\end{abstract}

Key words: Demographic Variables, Consumer Purchase Decision, Logistic Regression

\section{Introduction:}

Demography is the study of the vital and measurable statistics of a population (Schiffman, et al, 2004). The demographic variables are age, gender, marital status, family size, family life cycle, income, occupation, education, religion, race, generation, nationality and social class (Kotler, 2003). Demographics are used to describe a population in terms of its size, distribution and structure. Size means the number of individuals in a population while structure describes the population in terms of age, income, education and occupation. Distribution of the population describes the location of individuals in terms of geographic regions and rural, urban or suburban locations. Each of these factors influences the behaviour of consumer and contributes to the overall demand for various products and services (Hawkins, et al, 1995). Consumer behaviour is concerned with the study of factors that influence people's behaviour in a buying situation (Mahatoo 1985). Marketers can make better marketing decisions only when they know why and how individuals make their consumption decisions. If marketers are able to understand the behaviour of consumers precisely, they could predict how consumers are likely to react to various informational and environmental aspects and could shape their marketing strategies in such a way that they can achieve a great competitive advantage in the market.

\section{Conceptual Framework:}

Like psychological and social variables, demographic variables are also considered as the personal buying decision variables (Adcock, Bradfield, Halbord and Ross 1998). Barry (1986) defines demography as the study of population characteristics. These characteristics describe people - who are there, where they live, and where they are moving. Evans and Berman (1984) state demographics are easily identifiable and measurable statistics that are used to describe the population. Trends in population size indicate future potential and thus, influence market plans. The size of the population indicates the potential market demand for consumer products and services. Oldroyd (1989) notes demography is an important demand condition, helping the marketer to predict both size and change in target markets. Demographic factors have a bearing on the types of product which individuals want where they shop and how they evaluate possible purchases (Lancaster and Massingham 1998).

Marketers combine demographic, social and psychological data and study consumer decision making in order to better understand the consumers. These dimensions help to explain consumer life styles; the ways the people live. By understanding consumers, a firm is able to determine the most appropriate audience whom to appeal and the combination of a marketing factors that will satisfy this audience. So, it is imperative for marketers to use demographic data in conjunction with and part of social, psychological and consumer decisionmaking analyses. Evans and Berman (1984) claim that a person's demographic background has a strong influence in the life style or in the way of living adopted. The demographic information helps to locate a target market whose motives and behavior can then be explained and predicted using psychological or social cultural investigation. Demographic information identifies potential for sales and consumption of product although it 
does not identify why or by whom a particular brand is used. It is also relatively accessible and cost-effective to gather. Further, the demographic variables reveal trends relevant to marketers such as shifts in age and income distributions, etc. They can establish consumer profiles that may present attractive market opportunities. These are the causes why marketers, in growing numbers, are using demographic statistics for developing marketing strategies and programmes.

Consumer behavior is not just making a purchase decision or the act of purchasing; it includes the full range of experiences associated with using or consuming products and services. It also includes a sense of pleasure and satisfaction derived from possessing or collecting 'things'. The outputs of consumption are changes in feelings, moods, or attitudes; reinforcement in lifestyles; an enhanced sense of self; satisfaction of a consumer-related need; belonging to groups; and expressing and entertaining oneself. A consumer's decision to purchase or not to purchase a product or service is an important moment for most marketers. It can signify whether a marketing strategy has been wise, insightful, and effective, or whether it was poorly planned and missed the mark. Thus, marketers are particularly interested in the consumer's decision-making process. For a consumer to make a decision, more than one alternative must be available. In executing a purchase intention, the consumer may make up to five purchase sub decisions: a brand decision, vendor decision, quantity decision, timing decision and payment - method decision (Kotler, Philip2003).

\section{Literature Review:}

After searching and evaluating, the first outcome will be the decision to purchase or not to purchase the alternative evaluated as most desirable. If the decision is to buy, a series of related decisions must be made regarding the features, where and when to make the actual transaction, how to take delivery or possession, the mode of payment and other issues. So, the decision to make a purchase is really the beginning of an entirely new series of decisions that may be as time consuming and difficult as the initial one. Selecting a source from which to make a purchase is one of the buying decisions (Stanton, Etzel and Walker, 1994). A consumer's decision to modify, postpone or avoid a purchase decision is heavily influenced by perceived risk. The amount of perceived risk varies with the extent of money at stake, the amount of attribute uncertainty and the amount of consumer's self confidence. Marketers must understand the factors that provoke a feeling of risk in the consumer and provide information and support to reduce the perceived risk (Kotler, 2003).

Peterson, Balasubramanian and Bronnenberg (1997) forecast that early in the twenty first century consumers will be purchasing food and other basic household needs via in-home television computer systems. The shopper will make choices after viewing brands and prices on the screen. So, the purchasing process itself may change dramatically in the coming decades. Lilien, Kotler and Moorthy (1999) reveal that a consumer's purchase intention is influenced by changes in anticipated situational factors. The consumer forms a purchase intention on the basis of such factors as expected family income, the expected total cost of the product and the expected benefits of the product. Furthermore, when the consumer is about to act, unanticipated situational factors may intervene him from so (such as lack of availability of a preferred product). Hence, preferences and purchase intentions are not completely reliable predictors of actual buying behavior: while they guide purchase behavior, they fail to include a number of additional factors they may intervene. Demographics are uncontrollable variables in the external environment. The basis for any market is people. Hence, studying the population in terms of its demographic structure is very significant for marketing managers.

\section{Research Methodology:}

This study is descriptive in nature. The purpose of this study is to predict the purchase decision of a consumer to buy a car when his/her exact demographic profile is known. For this purpose, primary data have been collected from 405 car owners who bought their car during the year 2010-11 in Chennai city. Simple random sampling method has been adopted for identifying samples from the population. A specific questionnaire was developed for this study and the same was used to collect data from the respondents.

The researcher has used Logistic Regressionas a part of model building. Logistic regression is a variation of the regression model, wherein the dependent variable is a categorical variable. The logistic regression also allows the independent variables to be categorical variables. The logistic regression is nothing but the non-linear transformation of linear regression. The researcher has used the binary logistic regression, where the dependent variable is a dichotomous variable like ability to buy small car (yes or no decision). The regression value will range between 0 and 1, indicating the unwillingness by 0 and the willingness by 1 . The model fit is tested using the 'percent correct prediction' which is calculated based on the estimated palue (event occurring). The bigger the percent correct predictions, the better the mode. SPSS package has been used for analyzing the data using logistic regression for predicting the purchase decision of consumers. The hypothesis for this study is as follows:

\section{$H o=$ there is no relationship between the different demographic variables of consumers and their purchase decisions.}




\section{Results and discussions:}

The purchase decision of a consumer for buying a car $(\mathrm{Y})$ is considered to be depending upon the following independent variables $\left(\mathrm{X}_{\mathrm{i}}\right)$ : Age $\left(\mathrm{X}_{1}\right)$, Gender $\left(\mathrm{X}_{2}\right)$, Marital Status $\left(\mathrm{X}_{3}\right)$, Education $\left(\mathrm{X}_{4}\right)$, Occupation $\left(\mathrm{X}_{5}\right)$, Monthly Income $\left(\mathrm{X}_{6}\right)$, Monthly Family Income $\left(\mathrm{X}_{7}\right)$, Type of Family $\left(\mathrm{X}_{8}\right)$, Size of the Family $\left(\mathrm{X}_{9}\right)$, Number of dependents $\left(\mathrm{X}_{10}\right)$, Place of birth $\left(\mathrm{X}_{11}\right)$, House Ownership $\left(\mathrm{X}_{12}\right)$, Club Membership $\left(\mathrm{X}_{13}\right)$, Social Class $\left(\mathrm{X}_{14}\right)$, and Family life cycle $\left(\mathrm{X}_{15}\right)$

\subsection{Logistic Regression Model for determining the purchase decision of consumers for buying premium} car:

The researcher has developed a logistic regression model for determining the purchase decision of consumers for buying premium car. The final iteration results of the logistic regression model are given in Table 1. For selecting the significant demographic variables, the researcher has used forward likelihood ratio method of logistic regression analysis.

Table 1: Independent variables Included in the Logistic Regression Model for Determining the Purchase Decision for Buying a Premium Car

\begin{tabular}{|l|l|l|l|l|l|l|}
\hline Variables & B & S.E & Wald & df & Sig & Exp (B) \\
\hline (Constant) & 16.940 & 3.548 & 25.507 & 1 & 0.000 & 22747278 \\
\hline$X_{7}$ & -1.919 & 0.478 & 16.078 & 1 & 0.000 & 0.147 \\
\hline$X_{10}$ & -0.371 & 0.135 & 7.625 & 1 & 0.006 & 0.690 \\
\hline$X_{11}$ & -0.897 & 0.318 & 7.974 & 1 & 0.005 & 0.408 \\
\hline$X_{14}$ & -5.264 & 0.884 & 16.078 & 1 & 0.000 & 0.005 \\
\hline \multicolumn{7}{|l|}{ Hosmer and Lemeshow Test for Goodness of fit } \\
\hline Chi Square: 2.352
\end{tabular}

Source: Primary data

The following interpretations are made from the Table 1:

i) The Hosmer and Lemeshow Test for Goodness of fit indicates that the logistic regression model is a good fit ( $\mathrm{P}=0.968$ ) for the study data.

ii) The independent variables $X_{7}, X_{10}, X_{11}, X_{14}$ are included in the model, because the effects of these variables are significant $(\mathrm{P}<0.05)$

iii) The independent variables $\mathrm{X}_{1}, \mathrm{X}_{2}, \mathrm{X}_{3}, \mathrm{X}_{4}, \mathrm{X}_{5}, \mathrm{X}_{6}, \mathrm{X}_{8}, \mathrm{X}_{9}, \mathrm{X}_{12}, \mathrm{X}_{13}, \mathrm{X}_{15}$ are not included in the logistic regression model because they are not significant at $5 \%$ level of significance.

iv) The $\operatorname{Exp}(\mathrm{B})$ values for the respective independent variables indicate that

a) The purchase decision of a consumer who has more dependents $\left(\mathrm{X}_{10}\right)$ for buying a premium car is two-third times as that of a consumer who has less dependents.

b) The purchase decision of a consumer whose place of birth $\left(\mathrm{X}_{11}\right)$ is semi-urban, for buying a premium car is nearly half a time as that of a person was born in urban and so on.

c) The purchase decision for buying a premium car is almost same among all the consumers irrespective of their monthly family income.

d) The purchase decision for buying a premium car is almost same among all the consumers irrespective of their social classes.

v) The model developed from the analysis for the study is given below:

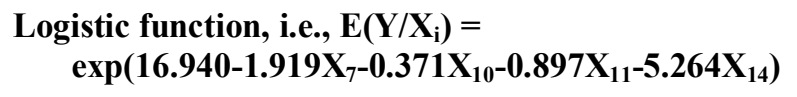

$$
1+\exp \left(16.940-1.919 X_{7}-0.371 X_{10}-0.897 X_{11}-5.264 X_{14}\right)
$$

The logistic function i.e. $\mathrm{E}\left(\mathrm{Y} / \mathrm{X}_{\mathrm{i}}\right)($ where $\mathrm{i}=7,10,11,14)$ gives the probability of a consumer for making a purchase decision to buy a premium car.

Table2: Classification table for the Dependent Variable (Purchase Decision for Buying a Premium Car)

\begin{tabular}{|l|l|l|l|l|}
\hline & Predicted & Percentage Correct & Overall Percentage \\
\hline Observed & 0 & 1 & & \multirow{2}{*}{88.6} \\
\cline { 1 - 4 } & 359 & 0 & 100 & \\
\hline $\mathbf{1}$ & 46 & 0 & 0 & \\
\hline
\end{tabular}

Source: Primary Data 
The above classification table reveals that about 88.6 percentage of the response regarding the purchase decision for buying a premium car is correctly classified based on the model development. This very high percentage (88.6\%) of classification further confirms the goodness of the model chosen for the analysis.

\section{Conclusion:}

The demographic variables have much significance in marketing. They are used as basis for segmenting the market and their role in consumer's buying decision is notable and vital. The important demographic variables are Age, Family size, Family life Cycle, Gender, Income, Occupation, Education, Religion, Race, Generation, Nationality, and Social class. Even when the target market is described in nondemographic terms (say, a personality type), the link back to demographic characteristics is needed in order to estimate the size of the target market and the media that should be used to reach it efficiently. So, identifying the demographic profile of the target consumers is very important for the marketers. From the findings of the study, the car marketers will be able to determine the purchase decision of consumers for buying car when the demographic profile is known.

\section{Acknowledgement:}

The author sincerely acknowledges Dr.S.Kaliyamoorthy, Director, Alagappa Institute of Management, Alagappa University, Karaikudi, Prof.S.Joseph Jeya Anand, Assistant Professor, VIT Business School, VIT University, Chennai and Mr.S.Alwin Reginald for their help in carrying out this study successfully.

\section{References:}

[1]. Adcock, Dennis, Ray Bradfield, Al Halbord and Caroline Ross, (1998), Marketing Principles and Practice, $3^{\text {rd }}$ ed., Financial Times Pitman Publishing: USA, pp 61-69.

[2]. Bary, Thomas (1986), Marketing - An Integrated Approach, The Dryden Press: USA, pp 127 - 162

[3]. Evans, Joel R. and Barry Berman (1984), Essentials of Marketing, Macmillan: USA, pp 78-104.

[4]. Hawkins, Del I, Roger I. Best and Kenneth A. Coney (1995), "Consumer Behaviour - Implications for Marketing Strategy", $6^{\text {th }}$ ed., Irwin Publishers, $\mathrm{p} 78$

[5]. Kotler, Philip (2003), Marketing Management, $112^{\text {th }}$ ed., Pearson Education Asia, pp 183-203.

[6]. Lancaster, Geff and Lester Massingham (1998), Essentials of Marketing, McGraw Hill Publishing Company, pp 51-66

[7]. Lilien, Gary L., Philip Kotler and Sridhar Moorthy, K. (1999), Marketing Models, Prentice Hall of India Pvt. Ltd.: New Delhi, pp 68107

[8]. Mahatoo, Winston H (1985), The Dynamics of Consumer Behaviour, John Weley\& Sons Canada Ltd., Toranto, Ontario, pp 5-8.

[9]. Oldroyd, Mike (1999), CIM Work Book-Marketing Environment, $4^{\text {th }}$ ed., Butterworth - Heinemann: UK, pp. 185-200.

[10]. Peterson, Robert A., Sridhar Balasubaramanian and Bart J. Bronnernberg (1997), 'Exploring the implications of internet for Consumer Marketing', Journal of the Academy of the Academy of Marketing Sciences, vol. 25, pp 329-346

[11]. Schiffman, Leon G. and Leslie LazerKanuk (2004), Consumer Behaviour, (8 ${ }^{\text {th }}$ ed.), Prentice Hall of India Pvt. Ltd.: New Delhi, $p 8$.

[12]. Stanton, William J., Michael J. Etzel and Bruce J. Walker (1994), Fundamentals of Marketing, $10^{\text {th }}$ ed., McGraw Hill Inc.: Singapore, pp $129-136$. 